\title{
Bronne vir Jesus-studies
}

\author{
P A Geyser \\ Departement Bybelkunde (Afd A) \\ Universiteit van Pretoria
}

\begin{abstract}
Sources for Jesus studies

The premise of this article is that historical research should not be predetermined in any way. All available sources should be utilized. Applied to historical Jesus studies, the implication is that the researcher cannot be restricted to the canon. The article focuses on the sources that are used for historical Jesus (re)construction. The Jesus tradition is chronologically stratified according to John Dominic Crossan's 'Inventory of the Jesus tradition by chronological stratification and independent attestation'. This inventory is to be found as an appendix to his 1991 book 'The historical Jesus'. However, the openness to extra-canonical sources does not provide us with any noticeable new information.
\end{abstract}

\section{INLEIDING}

In die ondersoek na die historiese Jesus, het die vraagstelling na bron(ne) op grond waarvan 'n profiel van Jesus gekonstrueer kan word, weer meer brandend na vore getree. Watter teks of tekste kan die beste lig bied op die historiese Jesus? In watter mate is die verskillende kanons wat bestaan, alreeds aanduiding van ideologieê met betrekking tot 'n profiel van Jesus? Gee die keuse vir kanon nie 'n prentjie van hoe mense hulleself reeds rondom ander kontensieuse en ideologiese kwessies geposisioneer het nie? Die blote feit dat daar in verskillende kerklike tradisies verskillende kanons bestaan en dat daar uitgegaan word van 'n sterk bindende gesag wanneer daar oor kanon gepraat word, konfronteer die moderne ondersoeker met 'n onvermydelike vraag.

* Hierdie artikel is 'n verwerking van die resultate van 'n deel van hoofstuk 3 van die DD-proefskrif, 'Die hermeneutiese uitgangspunte in die "nuwe historiese" benadering tot Jesus-studies', ingedien en aanvaar as deel van die vereistes vir die DD-graad, Departement Nuwe-Testamentiese Wetenskap, Fakulteit Teologie (Afd A), Universiteit van Pretoria, onder leiding van prof dr A G van Aarde. 
In enige akademiese besinning kan die kanonvraagstuk nie vanuit ' $n$ posisie van jou eie kerklike tradisie afgemaak word as finaal afgehandel, en daar bestaan nou nie verder enige vrae daaroor nie. Die vraag na die kanon is ' $n$ historiese vraag net soos die vraag na die Jesus van die geskiedenis. Daarom kan dit nie anders as dat ' $n$ mens hierdie saak in historiese reliëf sal plaas nie. In 'n opvolgende artikel sal ek ingaan op die kanonvrae wat ter sake is by historiese Jesus-studies. In hierdie artikel vestig ek eers die aandag op die bronne wat in die historiese Jesus-ondersoek benut word met spesifieke verwysing na die kronologiese stratifikasie van die Jesus-tradisie.

John Dominic Crossan (1991:427-450) bied in 'n appendiks 'n uitstekende en bruikbare 'Inventory of the Jesus tradition by chronological stratification and independent attestation.' Hierdie inventaris van Crossan is aangevul deur navorsing wat Andries van Aarde gedoen het tydens sy verblyf aan die Institute of Ecumenical and Cultural Research, Collegeville (MN), 1992-1993. Almal het in die verlede nie in alle opsigte met Crossan se indeling saamgestem nie, maar die opstel van so 'n databasis is deur beide Crossan en Van Aarde gedoen met verwysing na primêre bronne. Daar is ook genoegsaam ooreenkomste aanduibaar met ander navorsers, sodat ek dit as raamwerk aanvaar het vir hierdie afdeling.

\section{DIE KRONOLOGIESE STRATIFIKASIE VAN JESUS-TRADISIES IN VIER STRATA}

\subsection{Die eerste stratum 30-60 n C}

Die vroegste Christelike tekste waaruit hierdie stratum bestaan, het tot stand gekom in die jare 30-60 n C, alhoewel die jaartal 30 n C miskien tog te na aan die Jesus-gebeure staan. In hierdie laag kom die volgende tekste na vore: vier outentieke Paulus-briewe, naamlik 1 Tessalonisense, Galasiërs, 1 Korintiërs en Romeine. 1 Verder vind 'n mens in hierdie stratum die eerste laag van die Evangelie van Tomas. Hierdie dokument het onafhanklik van die 'intra-kanonieke evangelies' ontstaan. Met die begrip 'intrakanonieke' word bedoel alle biografiese en spreukagtige evangelies wat op die een of ander wyse die interteks vorm van die vier kanonieke evangelies, soos byvoorbeeld die Spreuke-evangelie $\mathbf{Q}$ wat intertekstueel in die Matteüs- en Lukasevangelie figureer. Die Tomas-evangelie is ook 'n spreukagtige dokument wat bestaan uit 'n versameling van gediskonnekteerde Jesus-woorde (met verskeie dialoē, maar geen wonderwerke en geen lydens- en opstandingvertellings nie) (kyk Davies 1983; Patterson 1993a). Dit is aan ons bekend in drie fragmentêre Griekse kopieë van die Oxyrhynchus-papiri en in 'n Koptiese vertaling in die Nag Hammadi-kodekse (kyk Crossan [1985] 1992:3-19). Hierdie vroeeer laag is ook bekend as die Jakobus-laag, en is waarskynlik van Jerusa- 
lem, rondom 50 n C te dateer (kyk Patterson 1993b:13; Miller 1992:302-303; Riley 1994:234).

Ook die oorspronklike samestelling van die Egerton Evangelie (onafhanklik van die intra-kanonieke evangelies) (kyk Crossan 1992:41-49; Daniels 1991:9-13; Miller 1992: 406-411); die Papyrus Vindobonensis [ook bekend as P. Vienna G. 2325] (bevind deur o a Von Harnack [kyk Crossan 1991:428] as onafhanklik — in Hennecke [1959] 1963: 115-116 bekend as die Fayyum-fragment); Papyrus Oxyrhynchus 1224 (vgl Miller 1992:416-418); die Evangelie van die Hebreërs (slegs bekend uit sewe patristiese aanhalings en onafhanklik van die intra-kanonieke evangelies; vgl Koester 1982:223-224); die Spreuke-evangelie $Q$ (met drie opeenvolgende lae in die ontwikkeling en terug te vind soos dit ingebed is in Matteus en Lukas; Kloppenborg [1987, 1988; contra Jacobson 1992] onderskei ook tussen drie lae: 'n wysheidslaag, 'n apokaliptiese laag en 'n 'inleidende' laag - vgl Mack 1993; Miller 1992:249-300); 'n Wondervertelling-versameling (ingebed in Markus en Johannes) (kyk Fortna 1988; Von Wahlde 1989); 'n 'apokaliptiese agtergrond' in Didache 16 en Matteus 24 (vgl Kloppenborg 1979:54-67) en die 'Kruisevangelie' (ingebed in die Evangelie van Petrus [kyk Fortna 1998:71-94] en volgens Crossan [1988] die enigste bron van die intra-kanonieke lydensvertellings maar vgl ook die standpunt van Koester 1990:220 wat voorstel dat ' $n$ enkele lydensbron onafhanklik van mekaar benut is deur Markus, Johannes en die Evangelie van Petrus).

\subsection{Die tweede stratum 60-80 n C}

In die tweede stratum kom daar agt dokumente voor: die Evangelie van die Egiptenare (slegs bekend uit ses aanhalings in patristiese literatuur en is onafhanklik van intrakanonieke evangelies) (kyk Koester 1980:238-256; Funk 1985:371); die Geheime Evangelie van Markus (volgens Crossan [1985] 1992:61-75] die eerste weergawe van die Evangelie van Markus) (kyk Smith 1973; Funk 1985:362-363; Miller 1992:402405; Koester \& Patterson 1991:14-16); die Evangelie van Markus (volgens Crossan die tweede weergawe van Markus); Papyrus Oxyrhynchus 840 (gefragmenteerde vertelling van 'n debat tussen Jesus en 'n Farisese hoëpriester wat formeel meer ontwikkeld is as die debatte in die Egerton Evangelie of Markus 7) (kyk Crossan 1991:430; Cameron 1982:53; Miller 1992:412-415); die tweede laag van die Evangelie van Tomas (die latere laag wat vermoedelik tussen 60-70 n C bygevoeg is in Siriese Edessa onder beskerming van beweerde Tomas-gesag); versameling van dialoe (ingebed in die Dialoog van die Verlosser en onafhanklik van die intra-kanonieke evangelies) (kyk Pagels \& Koester 1978:66-74; Miller 1992:336-350; Crossan 1991:430; Koester 1980: 255-256 - die Dialoog van die Verlosser bestaan hoofsaaklik uit 'n dialoog tussen die kurios en die dissipels Judas, Matteūs en Miriam; die finale redaksie van hierdie dokument het ongeveer 150 n C ontstaan; die dialoe is geskep as uitbreiding van 'n versameling 
Jesus-logia oor verlossing soos dit geskryf is in die Papyrus Oxyrhynchus 654 wat die Griekse fragment is van die tweede laag van die Evangelie van Tomas; die Dialoog van die Verlosser is oorspronklik in Grieks geskryf, maar is vandag alleen in die vorm van 'n fragmentariese Koptiese manuskrip uit Nag Hammadi bekend; die 'versameling van dialoë' is duidelik as bron grondliggend aan die Dialoog van die Verlosser te onderskei en 'shows a more developed dialogue format than in the Gospel of Thomas or the Sayings Gospel Q' [Crossan 1991:40]); die 'Evangelie van Tekens' ('n hipotetiese teks wat Fortna 1988 en Von Wahlde 1989 geïdentifiseer het wat deur die Evangelie van Johannes [hoofstukke 2-14] gebruik is); die Deutero-Pauliniese brief aan die Kolossense (kyk Miller 1992:175-194; Crossan 1991:430).

\subsection{Die derde stratum 80-120 n C}

In hierdie stratum vind mens negentien dokumente uit die laat eerste eeu en begin tweede eeu n C. Dit bestaan uit die evangelies van Matteus en Lukas; die Openbaring van Johannes; die Eerste brief van Klemens (onafhanklik van die intra-kanonieke evangelies); die Brief van Barnabas (ook onafhanklik van die intra-kanonieke evangelies); Didache 1:1-3a en 2:2-16:2 (onafhanklik van die kanonieke evangelies) (hierdie passasies moet onderskei word van 'n latere toevoeging, Didache 1:3b-2:1, wat onafhanklik is van die intra-kanonieke evangelies; ' $n$ apokaliptiese bron is ook te onderskei wat grondliggend lê aan Didache 16:3-5 en wat volgens Helmut Koester deur Markus in Mark 13 gebruik is, asook volgens Kloppenborg [1979] in Matt 24) (kyk Crossan 1991: 431; Draper 1985); die Herder van Hermas, Mandate 2:4-7 (onafhanklik van die intrakanonieke evangelies) (kyk Osiek 1994, 1997; Brox 1991:55-71; Crossan 1998a:394395); die Brief van Jakobus; die Evangelie van Johannes (kyk Fortna 1995: 12-16); die sewe briewe van Ignatius (Efesiërs, Magnesiërs, Tralliërs, Romeine, Filadelfiërs, Smirneane, Polikarpus); die Eerste Brief van Petrus; die Brief van Polikarpus aan die Filippense 13-14 (hierdie gedeelte is 'n brief wat vroeèr as hoofstukke 1-12 gedateer word; dit is gestuur as 'n begeleidende skrywe saam met 'n afskrif van Ignatius se briewe wat deur die kerk in Filippi versoek is) (kyk Koester 1982:306-308); en die Eerste Brief van Johannes.

\subsection{Die vierde stratum 120-150 n C}

In die vierde en finale fase word twaalf dokumente onderskei uit die periode 120-150 n C: 'n tweede uitgawe (volgens Crossan 1991:431-432) van die Evangelie van Johan-nes (Crossan meen daar is duidelik twee redaksies van die Johannes-evangelie wat onderskei kan word; die eerste uitgawe is die een waarna daar verwys is in die derde stratum, vroeg tweede eeu, wat ontstaan het onder druk van die sinoptiese evangelies se 
opgang; dit het bestaan uit ' $n$ kombinasie van die 'Evangelie van die Tekens' en sinoptiese tradisies, en op 'n kreatiewe manier is die 'Evangelie van die Kruis' [eerste stratum] ook benut; die tweede redaksie het nie net die sinoptiese evangelies se opgang onderstreep nie, maar het ook gedien as kritiek op die leiersfunksie van Petrus in die Jerusalemse Jesus-beweging, soos dit onder andere blyk uit die toevoeging van Johannes 21; ander toevoegings, wat Bultmann [(1964/1966) 1971:700-718] reeds geïdentifiseer het, soos Joh 1:1-18; 6:51-58; $15-17$ en gedeeltes oor die 'geliefde dissipel', kom waarskynlik ook uit hierdie laat fase); die Handelinge van die Apostels; die Protevangelium van Jakobus (kyk Cameron 1982:55-57; Miller 1992:323-333; volgens Crossan [1991:432] is daar agter hierdie dokument ' $n$ onafhanklike intra-kanonieke tradisie van Jesus-woorde wat teruggevoer kan word na die vyftigs n $\mathbf{C}$, maar as 'n eenheid kan dit nie meer as ' $n$ eerste-eeuse bron gesien word nie; daar is net een manuskrip wat nog in die Nag Hammadi-kodekse bestaan, wat 'n teks op papirus is en 'n Koptiese vertaling van 'n corspronklike verlore Griekse teks); die Eerste en Tweede Briewe aan Timoteus; die Tweede Brief van Petrus'; die Brief van Polikarpus aan die Filippense 1-12 (vgl die opmerking by die derde stratum; afhanklik van Matteus en Lukas); die Tweede Brief van Klemens (afhanklik van Matteus en Lukas, maar in geharmonieerde uittreksels hierdie brief kan volgens Koester [1982:233-236] die vroegste bekende anti-gnostiese geskrif uit Egipte wees; dit is ' $n$ traktaat wat aan die skrywer van 1 Klemens toegeskryf word, maar is volgens Crossan [1991:433] rondom 150 n C geskryf); die Evangelie van die Nasireërs (omtrent 23 uittreksels van Aramese of Siriese vertalings van 'n Griekse weergawe van Matteus wat bekend is uit patristiese aanhalings en kantlynaantekeninge in 'n familie van manuskripte, afkomstig uit 'n uitgawe van die sogenoemde 'Sion Evangelie', circa 500 n C; die vertaling dateer volgens Crossan 1991: 433 [vgl Koester 1982:201-202; Cameron 1982:97-98; Funk 1985:378-389] terug na rondom die middel van die tweede eeu n C); die Evangelie van die Ebioniete (hierdie evangelie is rondom $150 \mathrm{n} \mathrm{C}$ geskryf en was afhanklik van 'n geharmonieerde weergawe van Matteus en Lukas, moontlik ook Markus; al sewe uittreksels word aangehaal in Epifanius teen die einde van die vierde eeu. Epifanius het foutiewelik hierna verwys as die Evangelie van die Hebreërs - kyk Koester [1980] 1987:201-202; laasgenoemde evangelie is bewaar in Hiëronimus se kommentaar op Jesaja 4 - kyk Tatum 1994:89; die Evangelie van die Ebioniete se oorspronklike titel is onbekend [kyk Funk 1985:364370; Koester 1982:202-203; Cameron 1982:103-104]); Didache 1:3b-2:1 (hier kry 'n mens 'n versigtig geharmonieerde weergawe van spesifieke Jesus-logia uit Matteus, Markus en Lukas [kyk Layton 1968:343-383; Crossan 1991:433; 1998, appendiks 7]; die Evangelie van Petrus (volgens Crossan 1988 die redaksionele verwerking van die 
'Evangelie van die Kruis' [kyk eerste stratum] plus sommige komplekse van logia uit die kanonieke evangelies) (kyk Miller 1992:393-401; Funk 1985:291; Crossan [1985] 1992:87-128; 1998b:7-52; Dewey A J 1989, 1990, 1995, 1998:53-70).

\section{DIE PROBLEEM}

Hierdie oorsig van bronne wat die produkte is van die vroee Christendom, maak dit vir die ernstige eksegeet duidelik dat daar in die historiese ondersoek veel wyer gekyk moet word as na die latere gefikseerde Nuwe Testament-kanon wat bestaan uit sewe-entwintig boeke. Dit word ook duidelik dat daar agter hierdie dokumente van die Nuwe Testament ' $n$ hele wêreld van verweefdheid, onderlinge afhanklikheid en soms ook onafhanklikheid bestaan met betrekking tot hulle ontwikkeling en gebruik deur die vroegste Christene. In die ondersoek na die historiese Jesus, word alle beskikbare bronne benut. Dit was 'n leemte in die vorige (New Quest) ondersoek na die historiese Jesus wat kriteria vir die onderskeid tussen die historiese Jesus en die kerugmatiese Christus gebaseer het op die datering, kenmerke en aard van allén die kanonieke tekste. Dit was veral die Jesus Seminar wat 'n ernstige poging begin aanwend het om die historiese ondersoek te bevry van kwasi-legitimiteit, asof die geloofwaardigheid van die ondersoek sou staan of val by die feit dat dit slegs binne die raamwerk van die kanon (as 'norm' vir die kerk) kon geskied. Om die bronne vir Jesus-navorsing tot die Westers gebaseerde Nuwe Testament-kanon te beperk, ondermyn die geloofwaardigheid van die ondersoek as 'n historiese ondersoek volgens suiwer historiese kriteria.

Myns insiens moet die normatiewe funksionaliteit van die huidige Protestantse kanon gevind word in terme van die intensie waarom ' $n$ kerk ' $n$ kanon benodig. Die kerk het 'n kanon nodig as spreekreëls van die betrokke kerk se oortuigings (betrokke kerk kan ook in hierdie geval die katolieke kerk beteken). Dit is verstaanbaar dat 'n kerk 'n kanon nodig het vir die dinamiese aktiwiteite met die oog op liturgiese byeenkomste en institusionaliserende vormgewing. Indien die funksie van die kanon uitgebrei sou word om 'n akademiese ondersoek te pre-determineer, het ons met 'n onaanvaarbare uitbreiding van kanonieke funksionaliteit te doen. Wanneer die funksie van die kanon onder enige omstandigheid 'n beperking sou uitoefen op 'n ondersoek soos dié na die geskiedenis, geboorte en basis van die kerk, het ons met 'n akademiese inkonsekwentheid te doen. Roy W Hoover (1992:3) wys tereg daarop dat '... none of the canonical lists mentions inspiration as a criterion for determining which writings were to be included in the canon.' Die kerk is gebore en die basis is gele in 'n periode toe daar nog geen kanon was nie. Die resultate van so 'n historiese ondersoek kan wel beslissende gevolge hê vir die kritiese analise van die ontstaan en samestelling van die kanon. In die eerlike historiese ondersoek na die Jesus van die geskiedenis as die basis van die geboorte en ontstaan van die kerk, kan daar ook nie net volstaan word met ver- 
wysings na Jesus wat gevind word in kanonieke, intra-kanonieke en nie-kanonieke dokumente nie.

Dit bring die vraag na vore na die moontlikheid of daar nie ook buite die kring van vroeg-Christelike literatuur inligting oor Jesus bestaan nie. Ek ag dit om dié rede tog nodig om 'n kort ekskurs te maak in verband met ander moontlike bronne buite die dampkring van die Christelike beweging van die vroeẽ eeue.

\section{DIE GETUIENIS VAN NIE-CHRISTELIKE BRONNE}

\subsection{Inleiding}

Kee ([1970] 1977:42) sê dat dit natuurlik vir 'n historikus van onskatbare waarde sou wees indien ons enige direkte vermelding van Jesus in wetlike Romeinse dokumente gehad het. Ongelukkig bestaan dit nie. Die enigste dokument wat na daardie kant neig, is die verbeeldingryke apokriewe Acta Pilatus. Daarin word voortgebou op die kortlikse vermelding van Pilatus as Romeinse prokurator tydens die evangelies se voorstelling van die veroordeling van Jesus. Die geskrif het 'n denkbeeldige amptelike 'verslag' oor die veroordeling en teregstelling van Jesus (kyk Hennecke [1959] 1963:444483; Brown 1994:964-969).

Ongelukkig bied die verwysings na Jesus in Griekse en Latynse geskrifte van die eerste en vroeg tweede eeu so min dat dit, behalwe vir die Brief van Plinius, alles kortliks weergegee kan word. Dit is eintlik ook nie veel meer nie as kort sinspelings op die beweging wat in Jesus se naam begin het (kyk veral Crossan 1998a:2-18).

\subsection{Die Joodse historikus Josefus}

In sy geskrif Antiquitates wat hy in Grieks geskryf het, het Josefus (c37-100 n C) twee verwysings na Jesus. Dit is waarskynlik teen die agtergrond van die Joodse oorlog dat hy tydens die Romeinse inval van 67-70 n C ' $n$ meeloper van die invallers geword het en dat een van die verwysings na Jesus in 'n lys van berugte Joodse nasionaliste en moeilikheidmakers voorkom. Die tweede vermelding is in verband met die teregstelling van Jakobus, die leier van die Jesus-beweging in Jerusalem, wat Petrus 'onttroon' het, na wie verwys word as 'n 'broer' van Jesus. Die eerste verwysing (kyk Crossan 1998a:12) kan soos volg vertaal word:

Omtrent hierdie tyd het Jesus geleef, 'n wyse man, indien 'n mens hom 'n man behoort te noem. Hy het buitengewone dinge gedoen en was 'n leermeester van mense wat graag die waarheid aanvaar het. Hy het baie Jode en baie van die Grieke oortuig. Hy was die messias. Toe Pilatus, 
nadat hy aangehoor het hoe Jesus deur die leiersfigure onder ons beskuldig is, hom veroordeel het om gekruisig te word, het die mense wat in die eerste plek vir hom lief geword het, nie hulle gevoel vir hom prysgegee nie. Op die derde dag het hy aan hulle verskyn, herstel tot die lewe, soos wat die profete van God hierdie en ontelbare ander wonderlike dinge oor hom geprofeteer het. En die groep van Christene, so genoem op grond van hom, het tot vandag toe nie verdwyn nie (Josefus, Antiquitates 18.63-64).

Die tweede verwysing (kyk Crossan 1998a:14) kan soos volg vertaal word: ‘... hy [Ananus, die hoëpriester] het die regters van die Sanhedrin saamgeroep [in $62 \mathrm{n} \mathrm{C} \mathrm{ty-}$ dens die tussenregeertyd van die prefekte, Festus en Albinus] en 'n man met die naam van Jakobus en sekere ander mense voor hulle gebring. Hy was die broer van Jesus wat genoem is die Christus' (Josefus, Antiquitates 20.200).

Dit is die eerste verwysing wat in ondersoeke die meeste aandag geniet. In die huidige vorm daarvan lees die teks byna asof Josefus 'n oortuigde volgeling van Jesus was. Feldman (1984:679-703), 'n bekende Joodse geleerde, is van mening dat die sin: 'Hy was die Messias', weggelaat moet word as 'n latere Christelike interpolasie. Die res kan volgens hom gelees word as Josefus se verslag oor wat die Christene aangaande Jesus geleer het. Wat ons in elk geval hier vind, is:

* Jesus se dood word in verband gebring met Pontius Pilatus;

* sy dood deur kruisiging word gespesifiseer;

* daar word verwys na sy buitengewone dade;

* sy wysheid en leraarsrol word vermeld;

* Jode en nie-Jode (Grieke) het op sy boodskap gereageer;

* sy beweging het nie na sy dood opgehou bestaan nie;

* die getuienis van Jesus se volgelinge dat Jesus aan hulle verskyn het;

* dat dit alles vervulling van profetiese uitsprake was.

Daar is verskil van mening oor die bedoeling van die woorde: 'as 'n mens hom 'n man kan noem'. Dit sou kon impliseer dat Jesus Goddelik was. Myns insiens behoort dit egter saamgelees te word met die uitdrukking 'buitengewone dade'. So gesien, kan dit impliseer dat dit toorkuns was en dat Jesus onder die invloed van demoniese magte opgetree het. Dit was nie net die mees algemene aanklag teen Jesus in Rabbynse bronne nie, maar ons vind iets daarvan ook in die kanonieke evangelies dat Jesus met 
die gesag van Beëlsebul, die prins van die demone, opgetree het (Mark 3:22; Matt 9: 34). In hierdie buite-Bybelse getuienis is daar dus geen ontkenning dat Jesus buitengewone dade gedoen het nie. Die kwessie is alleen oor die bron van sy gesag of krag. Malina \& Neyrey (1988) het cortuigend aangetoon hoe die funksionering van etikettering in die eerste-eeuse Mediterreense kultuur op Jesus van toepassing gemaak is. Dieselfde optrede van 'n persoon kan of 'n vererende of 'n onterende benaming oproep by onderskeidelik bewonderaars of opponente.

Die tweede verwysing in Josefus handel oor die tydperk waar die stryd om mag in Joodse geledere in Judea aan die orde van die dag was. Dit was in die aanloop tot die Joodse opstand 66-70 n C. In hierdie periode het Jakobus, die broer van Jesus, die leierskap van die Jesus-beweging in Jerusalem van Petrus oorgeneem en het klaarblyklik ook die agting van die breër Joodse gemeenskap geniet. Die vermelding wat gemaak word deur Josefus dat hierdie Jakobus die broer van Jesus was, bied geen inligting verder oor Jesus nie. Dit bevestig slegs die (oordrewe) beeld wat 'n mens uit die evangelies kry dat Jesus 'n wel-bekende figuur in die eerste-eeuse Judaïsme was, wat ook so in die verbygaan geidentifiseer word as die Jesus wat deur sy volgelinge die Messias genoem is. Volgens Crossan (1998a:462-468) moet Jakobus gesien word as die 'skakel' tussen die ongeletterde kleinboerderygemeenskap van waaruit Jesus kom en die vroegste Christene wat bekend was vir hulle geletterde eksegetiese aktiwiteit. So gesien, help die teenwoordigheid van Jakobus in Jerusalem ons om iets te verstaan van 'n relatief duistere oorgang tussen Jesus as peasant en die eerste Jerusalemse gemeente wat in 'n stad (op 'n manier reeds geïnstitusionaliseerd - kyk Holmberg 1980:169170) op 'n hoë vlak die Ou Testament kon inspan om die cortuiging dat Jesus die Messias is, te legitimeer.

\subsection{Romeinse geskiedskrywers: Plinius, Suetonius en Tacitus}

Die oudste verwysing wat ons van Romeinse skrywers het, is een wat 'n mens vind in 'n brief van Plinius (ook genoem die Jongere, 62-113 n C). Plinius (Briewe 10.94-97 - kyk Crossan 1998a:4-8) skryf aan die keiser Trajanus rondom die jaar 110 n C vanaf Bitinië waar hy goewerneur was van die Romeinse provinsie in Klein-Asië aan die Swartsee (kyk Sherwin-White 1967). Hy vra leiding oor hoe hy moet optree teenor die Christene wie se getalle en invloed al groter geword het. Die invloed van hierdie Christelike geloof was so groot dat van die tempels van 'amptelike gode' byna verlate was in daardie gebied. Dié 'Christus' is aanbid as 'n 'god' en hy verwys na die feestelike samekoms waar die nagmaal en die liefdesmaal gevier is. Weer eens bied die stukkie getuienis nie veel wat nuut is nie. Dit bevestig dat die Christelike beweging vroeg in die tweede eeu sterk gestaan het in die gebied rondom die Swartsee, maar sy 
beskrywing van die praktyke van hierdie groep bied niks in verband met die lewe van Jesus nie.

'n Ander Romeinse historikus, waar ons 'n verwysing na Jesus kry, is Suetonius (Gaius Suetonius Tranquilius, Die lewe van die Caesars: Nero 16.2 - kyk Crossan 1998a:8-9). Hy was 'n tydgenoot van Plinius wat geskryf het oor die lewens van die twaalf Caesars. Hy vermeld dat daar in die regeertyd van Claudius (41-54 n C) 'n oproer onder die Jode losgebars het wat so 'n vlak van intensiteit bereik het, dat Claudius hulle uit Rome verban het. Die oorsaak van hierdie stryd was 'n persoon, 'n sekere 'Chrestos'. Daar word algemeen aanvaar dat hierdie 'Chrestos', wat 'n algemene naam was, deur Suetonius foutiewelik gegee is vir die minder bekende naam 'Christos'. Daarmee saam was die oorsaak van die oproer waarskynlik nie die koms van 'n sekere 'Chrestos' nie, maar die teenwoordigheid van Christelike predikers wat verkondig het dat Jesus die Messias ('Christos') was. Net soos in die geval van Plinius, is al wat ons werklik van Suetonius leer dat daar so vroeg as 49-50 n C reeds 'n Christelike gemeenskap in Rome was.

In sy Annales (15.44) skryf Tacitus (kyk Crossan 1998a:9; Jackson et al 1931: 226), 'n derde Romeinse skrywer van die vroeë tweede eeu, oor die vuur wat Rome vernietig het gedurende die tyd van keiser Nero (54-68 n C). Skynbaar om die blaam van homself af weg te kry, het Nero die Christene daarvan beskuldig dat hulle Rome aan die brand gesteek het. Daarna het verskriklike vervolging en lyding vir die groep mense wat deur die skares as 'Christene' beskryf is, gevolg. Volgens Tacitus is dit 'n naam wat hulle gekry het van die 'stigter van die beweging', naamlik 'Christus'. 'Christus' is in die regeertyd van Tiberius tereggestel, na die vonnis wat gevel is deur die prokurator Pilatus. Tacitus gee die omvangrykste en noukeurigste inligting wat nieChristelike skrywers oor Jesus bied. Die besonderhede kom ooreen met wat ons uit Christelike bronne weet, maar dit bied geen bykomstige inligting by wat ons in die evangelies vind nie.

\subsection{Joodse godsdienstige bronne}

Die Hebreeuse bronne waarin Jesus genoem word of na Hom verwys word, is al deeglik ontleed (kyk o a Klausner 1926:17-54). Die belangrikste bronne hiervoor is die mondelinge interpretasies en uitleg wat deur gesaghebbende rabbi's van die eerste en tweede eeue $\mathbf{n} \mathbf{C}$ gegee is, en wat in die derde eeu as die Mishna gekodifiseer is. Daarna is dit met addisionele kommentaar in die vierde eeu as die Jerusalemse Talmoed en in die vyfde eeu as die Babiloniese Talmoed uitgegee. Daar is dus ook kommentaar van rabbi's van die derde tot vyfde eeue $\mathrm{n}$ C in die Talmoed opgeneem, maar dit is die 
interpretasies van die sogenaamde Tannaim (van die eerste twee eeue) wat van primêre betekenis as historiese bronne vir die Joodse visie op Jesus beskou word.

In die algemeen kan oor die Joodse geskrifte gesê word dat dit baie min aandag aan Jesus gee en die enkele verwysings na Hom is polemies van aard en afkammend. Hierdie verwysings is ook ietwat verduister deurdat die Talmoed nêrens na Jesus op die naam verwys nie. Daar word na Hom verwys as 'n 'sekere persoon', of Balaam (Bileam), en daar word na Hom verwys as Ben Stada of Ben Pandira (variant Panthera). In elkeen van die gevalle waar die ben-verwysing voorkom, is dit bedoel as 'seun van' met die duidelike implikasie dat Jesus 'n buite-egtelike kind was (kyk Schaberg 1987: 170-173; Lüdemann [1997] 1998:56-58).

Die strategie van die Rabbynse tradisie was duidelik nie dat Jesus se bestaan ontken is nie, maar om Hom en sy ma sodanig te diskrediteer dat hulle as onwaardig beskou moes word om aan enige Goddelike doel te kon deelneem. Verder het die Rabbynse owerhede (net soos die Romeinse) klaarblyklik die leer van Jesus en van die vroeẽ kerk (insluitend Gnostiese oortuigings) so ernstig beskou, dat hulle gretig was om die beweging te diskrediteer as kettery en die volgelinge van sy naam te onderdruk. Klausner (1926:46) som die 'objektiewe' historiese gegewens wat uit die Tannaïtiese strata van die Talmoed afgelei kan word, soos volg op:

There are reliable statements to the effect that his name was Yeshu'a of Nazareth; that he 'practiced sorcery' (i.e. performed miracles, as was usual in those days) and beguiled and led Israel astray; that he mocked at the words of the Wise (the officially sanctioned interpreters of the Law); that he expounded scripture in the same manner as the Pharisees; that he had five (sic) disciples; that he said that he was not come to take aught away from the Law or to add to it; that he was hanged (crucified) as a false teacher and beguiler on the eve of the Passover which happened on a sabbath; and that his disciples healed the sick in his name.

Hierdie opmerkings van Klausner is duidelik gemaak in 'n vorige bedeling van wetenskaplike ondersoek. Dit geld nie net epistemologie nie, maar ook insig in die historiese betroubaarheid van sekere gegewens rondom Jesus. So, byvoorbeeld, is dit duidelik dat hy meen dat die Twaalftal meer histories sou wees as die verwysing deur die Tannaim na die vyftal dissipels. Vandag, wat byvoorbeeld die Twaalftal betref, is daar verskil van opinie onder Jesus-navorsers oor die historisiteit van die bestaan van twaalf dissipels wat deur Jesus geroep is. Die meer kritiese benadering is eerder van mening 
dat dit 'n skepping van die vroegste Jerusalemse Jesus-beweging was (kyk Meier 1997: 635-672 vir ondersteuners en teenstanders van die standpunt). Die verwysing na die buite-egtelike verwekking van Jesus het in die afgelope tyd weer besondere aandag by Jesus-navorsers gewek. In die algemeen betwyfel die kritiese ondersoek die historisiteit van hierdie afkammende verwysing van die Tannaim (kyk Meier 1991:22). Dit is egter verrassend dat Gerd Lüdemann (1998) in die onlangse verlede die historisiteit van hierdie verwysing verdedig. Wanneer die spektrum van die ondersoek uitgebrei word om die inligting oor Jesus in die Talmoed en Midrash van die vierde en later eeue in te sluit, is die inligting meer uitgebreid as dié van die Tannaim. Dit is egter terselfdertyd so laat en so klaarblyklik polemies dat dit as historiese getuienis waardeloos is. Dit blyk dat die gemelde verwysings na byvoorbeeld Jesus as 'magiër', sy kontroversies met die Fariseërs, die getal van sy dissipels en sy geboorte, die enigste gegewens bly wat vir die historiese Jesus-navorsing van waarde is.

\section{SLOTOPMERKINGS}

Dit het duidelik geword dat geen historiese ondersoek, daarom ook nie die ondersoek na die historiese Jesus, byvoorbaat ten opsigte van die bronne wat benut word, ingeperk kan word nie. Dit beteken dat die ondersoek na die historiese Jesus nie net die kanonieke en selfs die intra-kanonieke literatuur sal benut nie. Soos inligting beskikbaar kom oor bronne sal dit alles ontsluit en benut moet word indien so 'n historiese ondersoek wetenskaplike geloofwaardigheid moet behou. Dit is in der waarheid so dat die meeste historiese werk, soos met die ander sosiale wetenskappe, streef na konstante vernuwing in pogings om die konsensus te verskuif na nuwe en meer toereikende vlakke. Dit veronderstel natuurlik ook dat die gemeenskap van navorsers nie bevoorregte inligting vir hulleself hou nie, maar voortdurend met die gemeenskap van navorsers deel en daarna na buite. Sodoende kan kollegas eerlik met mekaar wees oor hulle vooronderstellings en selfs vooroordele en ook oor hulle resultate wat aan die gemeenskap deurgegee moet word.

Elke historikus moet 'n metode hê om diẹ werk te kan doen en dit sluit minstens die volgende in:

* Duidelikheid oor jou siening van bronne.

* Uitgespelde stappe oor die wyse waarop 'n mens met jou bronne wil omgaan sodat hulle inligting kan bied.

* Helderheid oor watter proses gevolg gaan word om die inligting op 'n realistiese en betekenisvolle manier te konstrueer. 
Die volgende kan geld as breẽ riglyne van hoe bronne beskou kan word (kyk Patterson 1998:262-265).

\subsection{Die voorrangposisie van Markus}

Die relatiewe orde en teorieë oor afhanklikheid van die drie sinoptiese evangelies word deur die meeste Nuwe Testamentici aanvaar. Markus het eerste geskryf, kort na die verwoesting van die tempel in Jerusalem (c 70 n C). Matteus en Lukas het onafhanklik van mekaar Markus in die een of ander vorm gebruik (c 80-95 n C).

\subsection{Die Spreuke-evangelie $\mathbf{Q}$}

Die gebruikmaking van die Spreuke-evangelie $Q$ gaan uit van die hipotese dat Matteus en Lukas elkeen ook ' $n$ tweede bron gebruik het wat in die navorsingsdebat bekend geraak het as $\mathbf{Q}$. Vroeër in die hoofstuk toe ek gehandel het oor die bronne wat vir Jesusstudies gebruik word, is gewys op die hipotese dat $Q$ een of meer redaksionele verwerkings ondergaan het. Aangesien $Q$ geen verwysing het na die katastrofiese gebeure van die verwoesting van die tempel nie, kan aanvaar word dat Matteus en Lukas gebruik gemaak het van 'n vroeëre weergawe van $Q$. Dit word algemeen aanvaar dat die finale dokument in die jare 50-60 n C ontwikkel het.

\section{3 'Sondergut' van Matteus en Lukas}

Hoewel daar duidelike konsensus daaroor is dat van die stof in Matteus en Lukas wat nie aan Markus of $Q$ toegeskryf kan word nie, relatief laat ontstaan het en waarskynlik in die kerklike gemeenskappe aan wie hierdie evangelies gerig is, is daar tog ook duidelik gedeeltes in Matteus en Lukas wat die vormhistoriese kritiek terugvind in besondere bronne wat Matteus (M) en Lukas (L) gebruik van gemaak het.

\subsection{Die Evangelie van Tomas}

Daar bestaan geen algemene konsensus oor die vraag van die verhouding tussen die Evangelie van Tomas en die sinoptiese evangelies nie. Dit is 'n dokument waarin antieke logia kumulatief versamel is. Ek het vroeër daarop gewys dat sommige navorsers van oortuiging is dat die Evangelie van Tomas 'n evangelietradisie verteenwoordig wat basies outonoom staan teenoor die sinoptiese tradisie. Daar is wel op 'n later stadium tradisies daarin opgeneem wat beïnvloed kon wees deur populêre wyd-voorkomende tradisies wat uit die kanonieke evangelies afgelei kon word. Die oorsprong van hierdie tradisies kon so vroeg gewees het as dié wat ons in $Q$ terugvind, maar daar is ook 'n saak daarvoor uit te maak dat Tomas die vorm waarin dit nou bestaan aangeneem het in 
'n tydperk wat min of meer ooreenkom met die skryf van die kanonieke evangelies (iewers tussen 65 en 95 n C) (vgl Baarda 1997; Van Eck 1997:632-642).

\subsection{Die Evangelie van Johannes}

Die konsensus wat tussen die meeste Nuwe Testament geleerdes tans bestaan, maak dat daar nie swaar geleun word op die Evangelie van Johannes vir inligting oor die historiese Jesus nie. Daar is slegs enkele gevalle waar dit lyk asof Johannes onafhanklike inligting bied wat ons nie in die sinoptiese tradisie of in Tomas vind nie. In die geval van die lydensnarratief kan Johannes se onafhanklikheid van die sinoptiese tradisie aangetoon word, alhoewel daar sommige geleerdes is wat meen daar is 'n gemeenskaplike bron agter Johannes, Markus en die Evangelie van Petrus. Vroeër het ek daarop gewys dat dit 'n ooreenkoms kan hê met Crossan se hipotese met betrekking tot 'n vroeë Kruisevangelie. Dit beteken dat ons Johannes, Markus en Petrus nie as onafhanklike meervoudige getuies van die verhoor en dood van Jesus kan beskou nie.

\subsection{Die Briewe van Paulus}

Hierdie skat van die Christelike literatuur kom selde in aanmerking vir die bespreking van die historiese Jesus, om die eenvoudige rede dat Paulus selde oor Jesus in historiese verwysing praat. Tog kan Paulus nuttig wees, nie net in die gevalle waar hy bepaalde Jesus-tradisies oordra nie, maar veral in sy uitsprake oor die Christelike geloof, beskouings oor God en die gemeenskapslewe in navolging van Christus. Hierdie gegewens moet ernstig geneem word omdat Paulus die oudste getuie is en hierdie getuienis van hom wortels het in die vroegste Jesus-beweging. Van Aarde ([1998]:301-307) het in hierdie verband 'n saak probeer uitmaak dat daar 'n saaklike kontinuïteit bestaan tussen Jesus wat God Vader noem en Paulus wat Christene aangenome kinders van God noem en wat as Gees-gevulde mense ook God as Vader aanroep. Van die ander aspekte waar Paulus direk of indirek diepgewortel is in die Jesus-tradisie kan van die volgende sake wees:

* sy kritiek op hiërargie;

* sy stryd teen 'etniese' suiwerheid as ideologie waarvolgens God alléén God vir Israel sou wees;

* sy erkenning van vroue in leiersposisies;

* sy algemene kontra-kulturele gesindheid; 


\subsection{Nie-Christelike bronne}

Ek het vroeër ook daarna verwys dat daar ook nie-Christelike bronne is waarin Jesus genoem word. In die bestudering van hierdie bronne sal 'n mens moet waak teen die onrealistiese verwagtings dat hulle 'n meer uitgebreide en neutrale weergawe bied. Die probleem is (soos ek reeds daarop gewys het) dat hierdie bronne, soos dié van Tacitus en Josefus, nóg uitgebreid nóg neutraal in hulle weergawes is. Die houding dat ' $n$ mens oop is ten opsigte van bronne is 'n sine qua non vir historiese ondersoek. Maar dit het geblyk dat nie-Christelike of selfs buite-kanonieke bronne tot dusver nog nie soveel inligting gebied het nie dat dit ons in staat stel om tot ' $n$ ingrypend ander konstruksie van die historiese Jesus te kom as wat die geval was by hulle wat hulle tot die kanonieke bronne beperk het.

\section{Endnotas}

1 Paulus se 'tweede' brief aan die Korintiërs, asook sy briewe aan die Filippense en Filemon, word vanweë verskillende redes nie in die inventaris opgeneem nie. In die cerste plek bevat hierdie briewe nie uitdrukkings soos bv: 'Ek het van die Kurios ontvang ....' [1 Kor 11:23] of 'die Christus volgens die sarx' [Rom 9:5]) wat die moontlikheid open dat gevra kan word na Paulus se kennis (of gebrek aan kennis) van Jesus nie. In die tweede plek word daar van die historieskritiese aanname uitgegaan dat beide 2 Korintiërs en Filippense 'n saamgeflanste versameling van fragmente van verskillende briewe van Paulus is wat na verskillende sosiale lokaliserings en daterings terug te voer is. 2 Korintiërs onderverdeel in ten minste 2 Korintiërs 1:1-2:13 (voortgesit deur 2 Kor 7:5-16), 2 Korintiërs 2:14-6:13 (voortgesit deur 2 Kor 7:2-4) en 2 Korintiërs 6:14-7: 1. Hierbenewens moet 2 Korintiërs 8 en 2 Korintiërs 9 as parallelle gesien word wat die kollekte vir die armes in Judea as tema het, maar wat respektiewelik eers die Masedoniese gemeentes as voorbeeld vir die gemeentes in Agaje voorhou en dan die gemeentes in Agaje as voorbeeld vir dié in Masedonië (vgl Van Aarde \& Pelser 1995:30-32). Filippense onderverdeel in Filippense 1:13:1, Filippense 3:2-4:1 en Filippense 4:2-21 (vgl Van Aarde \& Pelser [1993] 1995:16-17).

2 Die brief aan Titus is een van die sogenaamde 'Pastorale Briewe'. Hierdie brief word nie in die inventaris opgeneem nie, omdat dit onder andere nie uitdrukkings soos 'saad van Dawid' (kyk Rom 1:3-4 en 2 Tim 2:8) bevat nie. Hierdie besondere uitdrukking word soms foutiewelik (kyk Schaberg 1994:19 nota 35) verstaan as verwysend na die 'historiese Josef'. Hoewel dit in 'n voor-Pauliniese formule voorkom, is ook so 'n uitdrukking die warskynlike produk van die vroegste Jerusalemse Jesus-beweging. Titus, net soos Jakobus, verteenwoordig daardie geskrifte wat spore van Paulinisme bevat. Die navorsing oor Jakobus toon 'n duidelike baie laat ontwikkeling van die wysheidstradisie wat in die Spreuke-evangelie $Q$ terug te vind is (vgl bv die raakpunte met die berg/veldrede van Jesus). Dit word oorweeg as 'n bron vir Jesus vanweë hierdie raakpunte, hoewel dit duidelik latere gemeente-tiek vanuit die derde stratum verteenwoordig. Ook die brief van Judas ontbreek in die lys van bronne vir Jesus-studies. Hierdie brief (afgesien van die interafhanklikheid met 2 Petrus) het gein betrekking op die historiese Jesus nie, maar wel op 'apostels' wat met die historiese Jesus niks te doen het nie. Die brief bevat ook 'n aanhaling van 'n nie-Christelike apokaliptiese geskrif, Henog 1:9. Hebreërs word nie in die inventaris opge- 
neem nie, omdat hierdie geskrif 'n duidelik voorbeeld is van hoe daar deur middel van onder andere Jesus-benamings oorgegaan is vanaf Jesus as subversief teen die tempelideologie na Jesus as 'draer' (hoewel met nuwe inhoud) van hierdie ideologie.

\section{Literatuurverwysings}

Aland, K 1962. The problem of the New Testament canon. London: Mowbray.

Baarda, T 1997. Concerning the date of the Gospel of Thomas. Ongepubliseerde voordrag gelewer by die Annual SBL Meeting, San Francisco, November 1997.

Brown, R E 1994. The death of the Messiah - From Gethsemane to the grave: A commentary on the passion narratives in the four gospels, Vol 2. New York, NY: Doubleday. (The Anchor Bible Reference Library.)

Brox, N 1991. Der Hirt des Hermas. Göttingen: Vandenhoeck \& Ruprecht. (Ergänzungsreihe zum kritisch-exegetischen Kommentar über das Neue Testament 7.)

Bultmann, R [1964/1966] 1971. The Gospel of John: A commentary, to by G R Beasly-Murray; general editor: R W N Hoare \& J K Riches. Philadelphia, PA: Westminster.

Cameron, R 1982. The other gospels: Non-canonical gospel texts. Philadelphia, PA: Westminster.

Crossan, J D [1985] 1992. Four other gospels: Shadows on the contours of canon. Sonoma, CA: Polebridge. (Originally published in 1985 by Seabury Books, Winston Press, Minneapolis MN.)

1988. The cross that spoke: The origins of the passion narrative. San Francisco, CA: Harper \& Row.

1991. The historical Jesus: The life of a Mediterranean Jewish peasant. San Francisco, CA: HarperSanFrancisco.

1998a. The birth of Christianity: Discovering what happened in the years immediately after the execution of Jesus. San Francisco, CA: HarperSanFrancisco. 1998b. The Gospel of Peter and the canonical gospels. Forum (New Series) 1/1, 7-52.

Daniels, J B 1991. The Egerton Gospel. The Fourth $R$ 4/5, 9-13.

Davies, S L 1983. The Gospel of Thomas and Christian wisdom. New York, NY: Seabury.

Dewey, A J 1989. 'And an anwer was heard from the cross ... ': A response to J Dominic Crossan. Forum 5, 103-111.

1990. 'Time to murder and create': Visions and revisions in the Gospel of Peter. Semeia 49, 101-127. 
Dewey, A J 1995. Four visions and a funeral: Resurrection in the Gospel of Peter. Journal of Higher Criticism 2/2, 33-51.

1998. The passion narrative of the Gospel of Peter. Forum (New Series) 1/1, 53-70.

Draper, J 1985. The Jesus tradition in the Didache, in Wenham, D (ed), The Jesus tradition outside the gospels, 269-287. Sheffield: JSOT Press. (Gospel Perspectives 2.)

Feldman, L H 1984. Josephus and modern scholarship (1937-1980). New York, NY: Walter de Gruyter.

Fortna, R T 1988. The Fourth Gospel and its predecessor: From narrative source to present gospel. Philadelphia, PA: Fortress.

1995. The Gospel of John and the historical Jesus. The Fourth $R 8 / 5 \& 6$, 12-16.

1998. A pre-Johannine passion narrative as historical source. Forum New Series) 1/1, 71-94.

Funk, R W 1985. New gospels parallels, Vol 2: John and the other gospels. Philadelphia, PA: Fortress. (Foundations \& Facets.)

Hennecke, E [1959] 1963. New Testament Apocrypha, Vol 1: Gospels and related writings, edited by W Schneemelcher and translated by R McL Wilson. Louisville, KY: Westminster.

Holmberg, B 1980. Paul and power: The structure of authority in the primitive church as reflected in the Pauline epistles. Philadelphia, PA: Fortress.

Hoover, R W 1992. How the canon was determined: How did the church decide which books belong to the New Testament? When was the decision made? The Fourth $R$ 5/1, 1-7.

Jackson, J et al 1931. Tacitus, Annales, IV. Cambridge, MA: Harvard University Press. (Loeb Classical Library.)

Jacobson, A J 1992. The First Gospel: An introduction to $Q$. Sonoma, CA: Polebridge. (Foundations and Facets.)

Käsemann, E 1968. The canon of the New Testament church and the unity of the church, in Essays on New Testament themes, 95-107. London: SCM.

Klausner, J 1926. Jesus of Nazareth, tr by H Danby. New York, NY: Macmillan.

Kee, H C [1970] 1977. Jesus in history. Harcourt: Brace Jovanovich, Inc.

Kloppenborg, J S 1979. Didache 16:6-8 and special Matthean tradition. ZNW 70, 5467.

1987. The formation of $Q$ : Trajectories in ancient wisdom collections. Philadelphia, PA: Fortress. (Studies in Antiquity and Christianity.) 
Kloppenborg, J S 1988. $Q$ parallels: Synopsis, critical notes, and concordance. Sonoma, CA: Polebridge. (Foundations and Facets Reference Series.)

Koester, H 1980. Gnostic writings as witnesses for the development of the sayings traditions, in The rediscovery of Gnosticism, Vol 1, 238-261. Proceedings of the International Conference on Gnosticism at Yale, New Haven, CT, March 28-31, 1978. Leiden: Brill. (The School of Valentinus. Studies in the History of Religions: Supplements to Numen 41.)

- [1980] 1987. Introduction to the New Testament, Vol 2. Philadelphia, PA: Fortress. (Hermeneia: Foundations and Facets.)

1990. Ancient Christian gospels: Their history and development. Philadelphia, PA: Trinity Press International.

Koester, H \& Patterson, S J 1991. Secret Mark. The Fourth R 4/3, 14-16.

Layton, B 1968. The sources, date and transmission of Didache 1.3b-2.1. Harvard Theological Review 61, 343-383.

Lüdemann, G [1997] 1998. The virgin birth: The real story of Mary and her son Jesus, tr by J Bowden. Harrisburg, PA: Trinity Press International.

Mack, B L 1993. The Lost Gospel: The book of $Q$ \& Christian origins. San Francisco, CA: Harper \& Row.

Malina, B J \& Neyrey, J H 1988. Calling Jesus names: The social value of labels in Matthew. Sonoma, CA: Polebridge.

Meier, J P 1991. A marginal Jew: Rethinking the historical Jesus, Vol 1: The roots of the problem and the person. New York, NY: Doubleday.

1997. The circle of the Twelve: Did it exist during Jesus' public ministry? JBL 116/4, 635-672.

McDonald, L M 1995. The formation of the Christian biblical canon. Revised and expanded second edition. Peabody, MA: Hendrickson.

Miller, R J (ed) 1992. The complete gospels: Annotated Scholars Version. Sonoma, CA: Polebridge.

Osiek, C 1994. An early tale that almost made it in the New Testament. Biblical Research 10/5, 48-54.

1997. The Shepherd of Hermas in context. Acta Patristica et Byzantina 8, 115-134.

Pagels, E \& Koester, H 1978. Report on the Dialogue of the Savior, in Wilson, McL R (ed), Nag Hammadi and Gnosis: Papers read at the First International Congress on Coptology (Cairo, December 1976), 66-74. Leiden: Brill. (NHS 14.)

Patterson, S J 1993a. The Gospel of Thomas and Jesus. Sonoma, CA: Polebridge. 1993b. The Gospel of Thomas and Jesus. The Fourth $R$ 6/3, 8-13. 
Patterson, S J 1998. The God of Jesus: The historical Jesus \& the search for meaning. Harrisburg, PA: Trinity Press International.

Riley, G J 1994. The Gospel of Thomas in recent scholarship. Currents in Research: Biblical Studies 2, 227-252.

Schaberg, J 1987. The illegitimacy of Jesus: A feminist theological interpretation of the infancy narratives. San Francisco, CA: Harper \& Row.

Schaberg, J 1994. The canceled father: Historicity and the NT infancy narratives. Paper presented at the Westar Institute's Jesus Seminar, Santa Rosa (CA), October 1994.

Sherwin-White, A N 1967. Fifty letters of Pliny, translation with commentary. New York, NY: Oxford University Press.

Smith, M 1973. The Secret Gospel: The discovery and interpretation of the Secret Gospel according to Mark. New York, NY: Harper \& Row.

Tatum, W B 1994. John the Baptist and Jesus: A report of the Jesus Seminar. Sonoma, CA: Polebridge.

Van Aarde, A G [1998]. Fatherless in Galilee: The search for Jesus child of God. Beplan om te verskyn in 1999.

Van Aarde, A G \& Pelser, G M M [1993] 1995. Corpus Paulinum: Inleiding en Teologie. Ongepubliseerde studiehandleiding (Tweede verwerking), Departement Nuwe-Testamentiese Wetenskap (Afd A), Universiteit van Pretoria.

Van Eck, E 1997. Die Tomas-evangelie: Inleidende opmerkings. HTS 53/3, 623-649.

Von Wahlde, U C 1989. The earliest version of John's gospel: Recovering the Gospel of Signs. Wilmington, DL: Glazier. 